\title{
Mineral Carbon Sequestration by Alkaline Waste and Its Use in Landfill
}

\author{
Niharika Pandey ${ }^{1}$, Bhupendar P. Singh ${ }^{2}$, A. k. Neema ${ }^{1}$, \\ ${ }^{1}$ Civil Engineering Department Indian Institute of Technology, New Delhi-110016, India \\ ${ }^{2}$ Assistant Professor Department of Environmental Studies Lakshmibai College, Delhi University, New Delhi - \\ 110052, India
}

\begin{abstract}
The Municipal Corporation of Delhi (MCD) is among the largest municipal bodies in the world. It provides its civic services about 18 million people (estimated population of Delhi). Environmental impacts of municipal solid waste (MSW) management like emissions of greenhouse gases (GHGs) have been greatly reduced by Technological advancements, environmental regulations, and emphasis on resource conservation and recovery. The aim of this work was to quantify the volume of $\mathrm{CO}_{2}$ emitted from MSW Landfill and sequester it with a view to reduce greenhouse gas emissions. The alkaline waste like construction and demolition (C\&D) waste or Hospital Incineration (HI) waste has ability to capture carbon dioxide. The theoretical carbon dioxide sequestration potential of C\&D waste and $\mathrm{HI}$ ash is $32.55 \%$ and $28.57 \%$ respectively through various models like Default methodology and Land GEM model.

Key Words: Municipal Solid Waste, Carbon Sequestration, Greenhouse Gases, Default methodology, Land GEM model
\end{abstract}

\section{INTRODUCTION}

India is the second most populated country in the world followed by China. The population growth of India is increasing in very fast rate and it is believed that it will be at top position in near future. There is high increase of urbanization and industrialization in all over world. It is estimated that by the year 2050 out of total population the urban population accounts $86 \%$ in developed countries and $64 \%$ in developing countries respectively (Tacoli, 2012; UNPD, 2012).

The population growth, urbanization and industrialization have led to number of land use and infrastructural challenges that include higher rate of MSW generation and challenges with its management (Singh et al, 2014). It was estimated that in 1990 about 1.3 billion MT of MSW was generated globally while at present time nearly after two decade, the yearly production of solid waste is about 1.6 billion MT. The cities, which have more than 100,000 populations, contribute to more than 72 per cent of the total MSW (Da Zhu P. et al., 2008). It is the general believe that the rate of waste generation is an index of socio-economic development of the country. The rate of MSW generation is more prominent in the developing countries because of their high rate of unplanned urbanization. According to Central Pollution Control Board (CPCB, 2005), the annual MSW generation in India ranges between 4055 million tons per year and this Fig. could be 270 million tons in 2047 (Fig. 1).

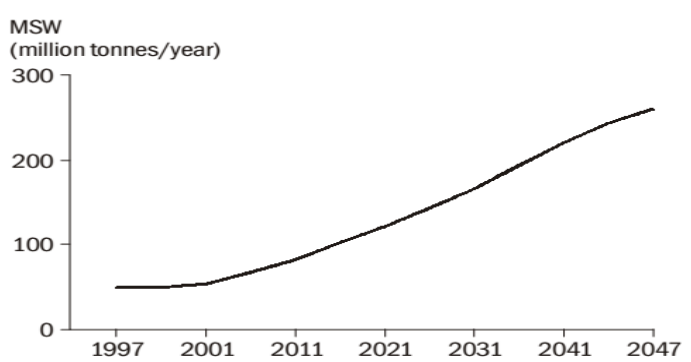

Fig.1. Projected trend of Solid Waste Management in India. Source (Singhal and Pandey, 2001)

The MSW is collected, segregated and finally dumped into the landfill. The municipal solid waste, which goes to landfill, has high amount of food and other biodegradable constituents. In Indian
MSW, which goes to landfill, has high amount of food and other biodegradable constituents (approximately 40-60\%). The other waste constituents are ash \& fine earth (30-40\%), paper (3- 
6\%) and plastic, glass and metals (each less than 1\%). During the course of time there is many bio-chemical reaction occurs in landfill through which this waste has been degraded (Sharholy et al., 2006; Shekdar, 1992; Thitame et al, 2010). The construction industry generates a significant amount of wastes from such as the land excavations, clearance of land, site work, building work, and demolition which lead to the generation of a significant amount of construction and demolition "C\&D" waste (Gupta et al., 2011; Shen et. al., 2004; Tam et. al., 2008). During the course of time there are many chemical reactions occur in landfill through which the MSW is degraded. This degradation leads to generation of mainly methane and Carbon dioxide $\left(\mathrm{CO}_{2}\right)$. The methane gas released is extracted and used up into energy production where it is converted into $\mathrm{CO}_{2}$. So that $\mathrm{CO}_{2}$ is, the major gas released from landfill site. The Table 1, shown clearly depicted the relation among urban population, per capita MSW generation and per capita carbon dioxide emission (World fact sheet, 2001, World Bank, 2003, CDIAC,).

Table 1. Increase in Urban Population of India

\begin{tabular}{|c|c|c|c|c|}
\hline Yeals & $\begin{array}{c}\text { Tilhall } \\
\text { population ( } \% \\
\text { int total) }\end{array}$ & $\begin{array}{c}\text { GIDP pel } \\
\text { capita } \\
(0)\end{array}$ & 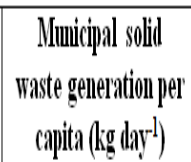 & $\begin{array}{l}\text { Pel' capita Calbont } \\
\text { dioxile enisssion } \\
\text { (ill metric touls) }\end{array}$ \\
\hline $2010^{\circ}$ & 12.28 & 5.3 & 0.75 & 1.3726 \\
\hline 2011 & 17.35 & 6.0 & 0.79 & 1.6404 \\
\hline 2030 & 32.43 & 7.0 & 0.97 & 3 to 5 \\
\hline
\end{tabular}

The first objective of the present study was to characterization of different quality control parameters and assessment of $\mathrm{CO}_{2}$ emission from municipal solid wastes. Second objective is estimate the alkaline waste alkaline waste from construction and demolition (C\&D) waste or Hospital Incineration (HI) waste.

\subsection{Literature Review}

Carbon sequestration refers to different methods that transfer atmospheric $\mathrm{CO}_{2}$ into longlived pools and keep it stored permanently so that it is not re-emitted back to atmosphere immediately (Lal et al. 2003). There are four type of process for carbon sequestration namely terrestrial carbon sequestration geological carbon sequestration, ocean sequestration and mineral sequestration. Mineral carbonation process is one of the best methods for carbon dioxide removal because it results permanent storage of carbon dioxide as mineral carbonate without any external energy inputs. Mineral carbon sequestration using alkaline waste is a new technology. The mineral carbon sequestration process has achieved more attention due to its exothermic reaction and raw material abundance. This carbonation process is thermodynamically favored and form lower energy state carbonates (Herzog, 2002). This method is one of the safest methods for $\mathrm{CO}_{2}$ sequestration in nature. This process involves the bringing in contact high conc. of $\mathrm{CO}_{2}$ with metal oxide, resulting in formation of stable carbonates for example reaction of $\mathrm{CO}_{2}$ with $\mathrm{Ca}$ or $\mathrm{Mg}$ form a final stable product such as $\mathrm{CaCO}_{3}$ and $\mathrm{MgCO}_{3}$ (Lackner et al. 2002, Fauth et al. 2005).Carbonation reactions have been investigated widely in alkaline waste, which shows that the alkaline waste is a feasible option to decrease the $\mathrm{CO}_{2}$ emission in the atmosphere (Huijgen et al. 2003; Bertos et al. 2004).Alkaline waste includes C\&D waste, fly ash, HI waste etc.

Construction industry is blooming in India so that quantity of $C \& D$ waste is also growing. The main constituents of $\mathrm{C} \& \mathrm{D}$ waste are $\mathrm{CaO}, \mathrm{MgO}$, $\mathrm{SiO}_{2}, \mathrm{Al}_{2} \mathrm{O}_{3}$ and $\mathrm{Fe}_{2} \mathrm{O}_{3}$ (Pappu et al. 2007). Various studies have been conducted so far shows that $\mathrm{C} \& \mathrm{D}$ waste have high potential in $\mathrm{CO}_{2}$ capture (Gupta et al. 2011). The reactions mechanism for carbonation reaction can be shown simply reaction of alkaline waste with $\mathrm{CO}_{2}$ as given below.

$$
\begin{aligned}
& \mathrm{CO}_{2(\mathrm{~g})}+\mathrm{H}_{2} \mathrm{O} \rightarrow 2 \mathrm{H}^{+}+\mathrm{CO}_{3}^{2-} \text { (aq) eq } 1 \\
& \mathrm{CaSiO}_{3(\mathrm{~s})}+2 \mathrm{H}^{+} \rightarrow \mathrm{Ca}_{(\mathrm{aq})}^{2+}+\mathrm{SiO}_{2}(\mathrm{~s})+\mathrm{H}_{2} \mathrm{O}_{(\mathrm{l})} \quad \text { eq } 1 \\
& \mathrm{Ca}^{2+}(\mathrm{aq})+\mathrm{CO}_{3}^{2-}(\mathrm{aq}) \rightarrow \mathrm{CaCO}_{3(\mathrm{~s})} \text { eq } 1 \\
& \mathrm{CaSiO}_{3(\mathrm{~s})}+\mathrm{CO}_{2(\mathrm{~g})} \rightarrow \mathrm{CaCO}_{3(\mathrm{~s})}+\mathrm{SiO}_{2}+90 \mathrm{~kJ} \mathrm{~mol}^{-1} \mathrm{CO}_{2} \text { eq } 1 \\
& \mathrm{Mg}_{2} \mathrm{SiO}_{4}+2 \mathrm{CO}_{2} \rightarrow 2 \mathrm{MgCO}_{3}+\mathrm{SiO}_{2}+89 \mathrm{~kJ} \mathrm{~mol}^{-1}+\mathrm{CO}_{2} \text { eq } 1 \\
& (\mathrm{Ca}, \mathrm{Mg}) \mathrm{SiO}_{3(\mathrm{~s})}+\mathrm{CO}_{2(\mathrm{~g})} \rightarrow(\mathrm{Ca}, \mathrm{Mg}) \mathrm{CO}_{3(\mathrm{~s})}+\mathrm{SiO}_{2(\mathrm{~s})} \text { eq } 1
\end{aligned}
$$

These reactions are exothermic in nature and favored at low temperature. The carbonate formation occurs spontaneously in nature due to natural $\mathrm{CO}_{2}$ rich fluids percolation into mineral 
deposits. The carbonates formed are stable and not likely to release the bound $\mathrm{CO}_{2}$ again into the

\section{METHODOLOGY}

MSW represent the largest mass of solid materials generated by humanity. As the population of the world is keeping on escalating, the MSW is also keep on rising. This generated MSW is goes either into the open dumping site or in the landfill. In the developing countries these organically rich solid waste generally disposed into open dump; only small fraction is processed by composting or vermi atmosphere.

composting. The first step in MSW management is the segregation of waste, which can be categorized into biodegradable waste and non-biodegradable waste. Before the final disposal of MSW into landfill sites or dump, major part of MSW is recycled, conducted by rag pickers. The Figure 2 given below describes the MSW management.

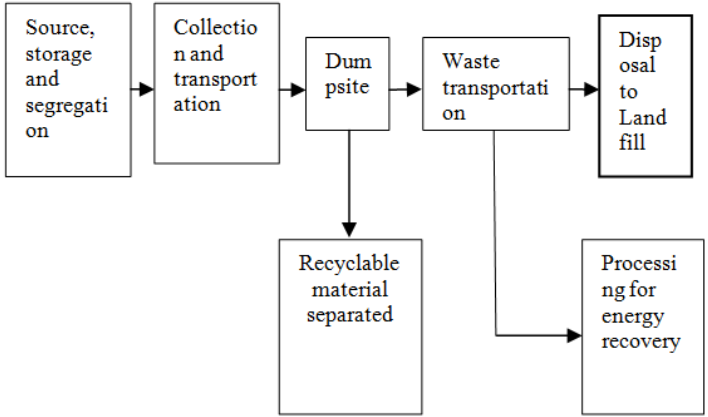

Figure 2. Flow chart of MSW management

Due to course of time the developing countries like India moves from open dump to sanitary landfill or bioreactor landfill. This bioreactor landfill contain surface water drainage system, environmental monitoring system, leachate collection and treatment system bottom liners, daily covers, and landfill gas collection system.

\subsection{Landfill Gas Generation}

The MSW that goes to landfill has high amount of food and other biodegradable constituents. During the course of time there are many chemical reactions occur in landfill through which the MSW is degraded as the time passes. This waste generation phase include five more or less sequential phase from Phase-I to Phase-V. Phase-I is aerobic decomposition phase in which $\mathrm{CO} 2$ gas is generated. The oxygen content in landfill decreases with time and anaerobic condition developed that leads to the onset of Phase-II i.e. transition phase. Due to course of time oxygen content is very less or absent within the landfill hence landfill reaction is strictly anaerobic. This phase is known as Phase-III or anaerobic phase. At offset of Phase-III, methanogen became active and methane gas emission becomes predominant (phase IV). The Phase $\mathrm{V}$ of the landfill is known as maturation phase. In maturation phase the biodegradable nutrient is very less so that the landfill gas emission is quite low. Landfill gas composition is presented in Table 2.

Table 2. Percentage composition of landfill gas

\begin{tabular}{|l|c|c|c|c|l|c|c|}
\hline Gases & Methane & $\begin{array}{c}\text { Carbon } \\
\text { dioxide }\end{array}$ & Nitrogen & Oxygen & Ammonia & NMOCs* & Sulfides \\
\hline $\begin{array}{l}\text { Percentage } \\
\text { content }\end{array}$ & $45-60$ & $40-60$ & $2-5$ & $0.1-1$ & $0.1-1$ & $0.01-0.6$ & $0-1$ \\
\hline
\end{tabular}

NMOCs * Non-methane organic compounds

\subsection{Delhi Landfill Sites}

In Delhi, India there is three-landfill site named Okhla, Ghazipur and Bhalaswa. These landfill sites are clearly shown in the Figure 3. Theses landfills are the sink for the MSW collected from whole Delhi. The description of landfill site with respect to starting year, locality, area covered and waste received until this time, is given in Table 3. 


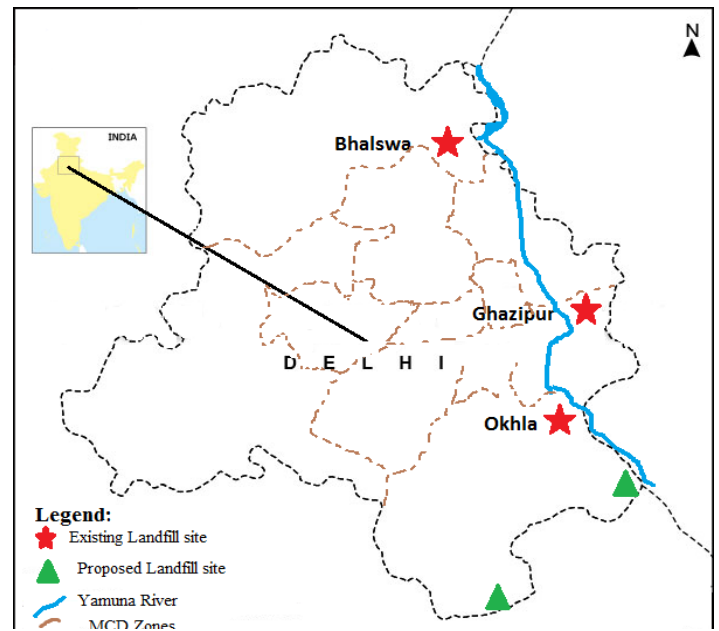

Figure 3. Location of existing landfill site in Delhi.

The landfills present in Delhi, India are well maintained as per Indian scenario. The waste acceptance for all the three landfills is given in Table 4. The annual waste acceptance and the structural features of sites affect the landfill gas emission. The landfill area of Gazipur Landfill (29.16 Ha) is higher than Bhalswa Landfill (21.06 Ha) and Okhla Landfill $(16.2 \mathrm{Ha})$. Hence, waste acceptance is high in Gazipur Landfill followed by Bhalswa Landfill and Okhla Landfill.

Table 3. Existing Landfill sites in Delhi

\begin{tabular}{|c|c|c|c|c|}
\hline $\mathrm{SN}$ & Features & Ghazipur & Bhalswa & Okhla \\
\hline 1 & Location & $\begin{array}{l}28 \quad 370 \\
22.400 \mathrm{~N}, \\
77 \quad 190 \\
25.700 \mathrm{E} \\
\text { (East Delhi) }\end{array}$ & $\begin{array}{l}28 \\
44027.1600 \\
\mathrm{~N}, \\
77 \\
27.9200 \mathrm{E} \\
\text { (North } \\
\text { Delhi) }\end{array}$ & $\begin{array}{l}28300420 \\
0 \mathrm{~N}, \\
77 \quad 160 \\
5900 \mathrm{E} \\
\text { (South } \\
\text { Delhi) }\end{array}$ \\
\hline 2 & $\begin{array}{l}\text { Started } \\
\text { year }\end{array}$ & 1984 & 1992 & 1996 \\
\hline 3 & $\begin{array}{l}\text { Year of } \\
\text { closure }\end{array}$ & 2012 & 2010 & 2011 \\
\hline 4 & $\begin{array}{l}\text { Area } \\
(\mathrm{Ha})\end{array}$ & 29.16 & 21.06 & 16.2 \\
\hline 5 & $\begin{array}{l}\text { Waste } \\
\text { Received }\end{array}$ & 2000 TPD* & 2200 TPD* & $\begin{array}{l}1200 \\
\text { TPD* }\end{array}$ \\
\hline 6 & $\begin{array}{l}\text { Waste } \\
\text { collected } \\
\text { from the } \\
\text { zone }\end{array}$ & $\begin{array}{l}\text { Shahdara } \\
\text { (North), } \\
\text { Sadar, } \\
\text { Paharganj } \\
\text { and NDMC } \\
\text { area }\end{array}$ & $\begin{array}{l}\text { Civil Line, } \\
\text { Karol Bagh, } \\
\text { Rohini, } \\
\text { West } \\
\text { Najagarh }\end{array}$ & $\begin{array}{l}\text { Central } \\
\text { and South, } \\
\text { Najafgarh } \\
\text { and } \\
\text { Cantonme } \\
\text { nt area }\end{array}$ \\
\hline 7 & $\begin{array}{l}\text { Annual } \\
\text { precipitat } \\
\text { ion } \\
\text { (mm/yea } \\
\text { r) }\end{array}$ & 706 & 706 & 706 \\
\hline 8 & $\begin{array}{l}\text { Density } \\
\text { (tones/m } \\
3 \text { ) }\end{array}$ & 1.2 & 1.2 & 1.2 \\
\hline 9 & $\begin{array}{l}\text { Technolo } \\
\text { gy used }\end{array}$ & $\begin{array}{l}\text { Aerobic } \\
\text { windrow } \\
\text { Composting }\end{array}$ & $\begin{array}{l}\text { Aerobic } \\
\text { windrow } \\
\text { composting }\end{array}$ & $\begin{array}{l}\text { Aerobic } \\
\text { windrow } \\
\text { compostin } \\
\mathrm{g}\end{array}$ \\
\hline
\end{tabular}

* TPD: Tones per Day. 
Table 4 Quantity of SW reaching Delhi landfill site

\begin{tabular}{lllll}
\hline \multirow{2}{*}{$\begin{array}{l}\text { Year- } \\
\text { wise }\end{array}$} & \multicolumn{3}{l}{ Waste Acceptance (in tons) } \\
\cline { 3 - 5 } & & $\begin{array}{l}\text { Bhalswa } \\
\text { Landfill }\end{array}$ & Okhla Landfill & Gazipur Landfill \\
1. & $2002-03$ & 69072 & 27216 & 1691083 \\
\hline 2. & $2003-04$ & 77009 & 31180 & 1907599 \\
\hline 3. & $2004-05$ & 82773 & 30004 & 1929465 \\
\hline 4. & $2005-06$ & 60236 & 35249 & 2061538 \\
\hline 5. & $2006-07$ & 54566 & 33736 & 1903583 \\
\hline 6 & $2007-08$ & 60674 & 30836 & 1524059 \\
\hline 7 & $2008-09$ & 69617 & 33807 & 1659741 \\
\hline 8 & $2009-10$ & 70134 & 37379 & 1845896 \\
\hline 9 & $2010-11$ & 58711 & 40554 & 2072873 \\
\hline 10 & $2011-12$ & 49366 & 41896 & 2080736 \\
\hline
\end{tabular}

\section{RESULT AND DISCUSSION}

\subsection{Methods for GHG Quantification}

The various researchers have constantly done the landfill gas estimation across the globe. There are various landfill model for estimating gas such as biochemical model, empirical model, Land GEM model and stoichiometric models. According to IPCC 1996 in Indian Scenario, Default method (DM) and first order decay (FOD) methods are recommended for LFG estimation.

\section{A. Default methodology (DM)}

It is an empirical model with a number of empirical constant. These empirical constant depend upon waste compositions and its management. Total carbon dioxide yield for the waste dumped into the landfill can be computed by using equation 1 .

Emission $=\left(\mathrm{MSW}_{\mathrm{T}} \times \mathrm{MSWF}\right)_{\mathrm{X}} \mathrm{MCF} \times \mathrm{DOC} \times \mathrm{DOC}_{\mathrm{F}}$ x F x (16/12-R) x (1-OX) Eq. 1

Where, $\mathrm{MSW}_{\mathrm{T}}$ is the total MSW reaching in the year 20011-12, i.e. 2080736 tones, 49366 tons and 41896 tons for Gazipur Landfill, Bhalswa Landfill and Okhla Landfill respectively. MCF (methane correction factor) is taken as 0.4 for unmanaged landfill site having depth $<5 \mathrm{~m}$, and based on waste composition DOC (Degradable organic carbon) value for Delhi is taken as 0.15. Default value for dissimilated organic fraction (DOCF) and fraction of methane in LFG (F) is $77 \%$ and $50 \%$, respectively. R (Recovered methane) and OX (Oxidation factor) is assumed zero for Delhi.

Total carbon dioxide gas generation is calculated for Gazipur Landfill, Bhalswa Landfill and Okhla Landfill are42934.81 tones, 49366 tones and 41896tons respectively in the year 20011-12. The waste acceptance in the time span of 10 years from 2002 to 2012 for Gazipur Landfill, Bhalswa Landfill and Okhla Landfill are 18676573 tones, 652158 tones and 341857 tonsrespectively. The total carbon dioxide gas generated from 2002 to 2012 for Gazipur Landfill, Bhalswa Landfill and Okhla Landfill are 385380.5 tones, 13456.91 tones and 7054.025 tonsrespectively. The carbon dioxide gas emission for all three landfill is summarized in the Table 5. Table 5. Estimation of $\mathrm{CO}_{2}$ gas emission from landfill by Default Method

\begin{tabular}{llccl}
\hline S.N. & Year & \multicolumn{3}{c}{$\mathrm{CO}_{2}$ gas emission (in tons) by } \\
Default Method
\end{tabular}




\section{B. Land gem model}

The estimation of landfill gases (LFG) is done through model stipulation. Here the Land GEM model is used to calculate the Landfill gas generation from the landfill. It is the automated tool developed by American Environmental Protection Agency (US E.P.A) to quantify landfill gases. This model is based on simple degradation equation. The model determines the mass of methane generated with the help of methane generation capacity and the mass of waste deposited. The Land GEM model can be described as

$$
Q_{C H_{4}}=\Sigma_{i=1}^{n} \Sigma_{j=0.1}^{1} k L_{0} \frac{\left(M_{j}\right)}{10}\left(e^{-k t}\right) \text { Eq. } 2
$$

Where, $i$ is the time elapsed in unit of year; $n$ is the difference between final and initial year of waste acceptance, $\mathrm{k}$ is the methane generation constant ( $\mathrm{yr}^{-}$ ${ }^{1}$ ) and $\mathrm{L}_{0}$ represents the methane generation potential in unit $\left(\mathrm{Mg} / \mathrm{m}^{3}\right)$. In the equationj is the 0.1 year time increment; $M_{i}$ the mass of degradable refuse waste at the initial time and $t_{i, j}$ is the age of the $j^{\text {th }}$ section of waste $\mathrm{Mi}$ accepted in the $\mathrm{i}^{\text {th }}$ year (decimal years). This model depends upon variables like Historic and projected waste disposal rates, Methane decay rate,Methane generation potential and Collection efficiency. The carbon dioxide gas estimation through Land GEM model is calculated (Table 6).

The input data used for the Land Gem model are methane generation rate $(\mathrm{k})$, methane content and potential methane generation capacity $\left(\mathrm{L}_{0}\right)$. The methane generation rate $(\mathrm{k})$ and potential methane generation capacity $\left(\mathrm{L}_{0}\right)$ for the bioreactor landfill are 0.050 year $^{-1}$ and $170 \mathrm{~m}^{3} / \mathrm{Mg}$ respectively. The methane content is $50 \%$ by volume. Through this model the total landfill gas emission, methane gas emission and carbon dioxide gas emission have been estimated as in Figure 4 given below. Here in this study the gas estimation is done for all the three landfills in Delhi through Land GEM model as shown in Table 6.

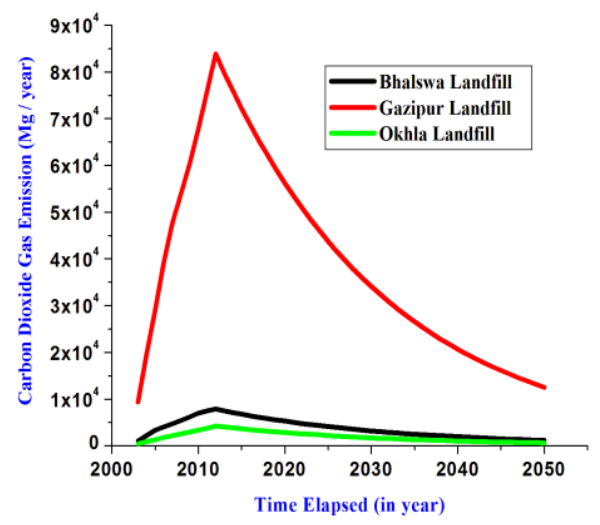

Figure 4. Annual carbon dioxide gas emission from landfill

The daily waste acceptance of Bhalswa landfill is comparatively more than Gazipur and
Okhla landfill. Hence, the gas emission from the Bhalswa landfill is also higher than other landfills.

Table 6. Estimation of $\mathrm{CO}_{2}$ gas emission from landfill by Land Gem

\begin{tabular}{lllll}
\hline & Year & \multicolumn{3}{l}{$\mathbf{C O}_{2}$ gas emission (in $\mathbf{m}^{3} / \mathbf{y r}$ ) by } \\
Land GEM Model
\end{tabular}

\subsection{Sequestration Of Carbon Dioxide Gas}

The landfill generally accepts the waste for 20 years and it is assumed that it can be utilized for LFG production up to 40 years. The $\mathrm{CO}_{2}$ production from landfill is continued even after closure of landfill. The alkaline waste is required to sequester $\mathrm{CO}_{2}$, as a daily cover of each cell within the landfill before its closure. The alkaline waste can also be 
provided as an intermediate cover between or around the LFG collection wells so that all the $\mathrm{CO}_{2}$ is captured within the landfill itself .Here in the study it is assumed that $50 \%$ of gets captured in one layer and the rest gets transferred to the above successive layer.

The $\mathrm{CO}_{2}$ produced till entire life span from landfill is calculated and found $2,779,568$ tones. The total
C\&D waste needed for whole life span of landfill is $8,539,379$ tones and HI waste needed is 9,728,974 tones. This shows C\&D waste is more useful for carbon sequestration in comparison to HI waste. Requirement of alkaline waste corresponding to $\mathrm{CO}_{2}$ emission is shown in Figure 5.

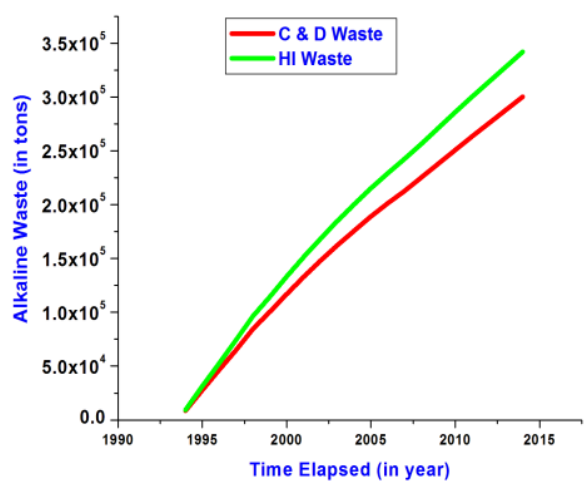

Figure 5. Alkaline waste required for conventional landfill

\section{CONCLUSION}

Capturing and separation of $\mathrm{CO}_{2}$ from landfill can be achieved through continued research, development and demonstration. This research is being performed to abate global climate change, which is consequence of GHG emission (IPCC, 2007). The mineral carbon sequestration is only known form of permanent solution for carbon storage in a single step. Silicate of calcium and magnesium minerals is often used for mineral carbonation but it requires energy intensive pretreatment to achieve optimized carbonation conversion and acceptable kinetics. Hence, certain alkaline wastes are used as an alternative source of mineral alkalinity. These alkalinewastes have their specific sets of advantages and disadvantages in term of $\mathrm{CO}_{2}$ sequestration. Therefore, it is difficult to compare them for mineral $\mathrm{CO}_{2}$ sequestration. Here in this paper two type of waste is considered namely $\mathrm{C} \& \mathrm{D}$ waste $\left(\mathrm{CO}_{2}\right.$ sequestration potential $32.55 \%)$ and $\mathrm{HI}$ waste $\left(\mathrm{CO}_{2}\right.$ sequestration potential 28.57\%) (Gupta et al. 2011). Due to high $\mathrm{CO}_{2}$ sequestration potential, $\mathrm{C} \& \mathrm{D}$ waste required is less in quantity in comparison to $\mathrm{HI}$ waste. These waste must have undergo through size reduction that increases the rate of carbonation reaction.

\section{ACKNOWLEDGMENTS}

IIT Delhi supported this research in collaboration of Council of Scientific and Industrial Research (CSIR) and Department of Science and Technology (DST).

\section{REFERENCES}

[1]. Beede, D.N., and Bloom, D.E., 1995, "The economics of municipal solid waste", World Bank Research Observor, vol.10, No.2.

[2]. Bertos, M.F., Li, X., Simons, S.J.R., Hills, C.D., and Carey, P.J., 2004, "A Review of Accelerated Carbonation Technology in the Treatment of Cement- Based Materials and Sequestration of $\mathrm{CO}_{2}$ ", Journal of Hazardous Materials, B112, 193-205.

[3]. Chalvatzaki, E., Lazaridis, M., 2010, "Estimation of greenhouse gas emissions from landfills: application to the Akrotiri landfill site (Chania, Greece)", Global NEST Journal, 12(1), 108-116.

[4]. CPCB, (2011). Status of solid waste generation, collection, treatment and disposal in metro cities, Central Pollution Control Board, Delhi. Demolition Alkaline Waste Material in Indian Perspective. World Academy of Science, Engineering and Technology. 78.

[5]. Da Zhu, P. U., 2008, Asnani Chris Zurbrügg Sebastian Anapolsky Shyamala Mani, Improving Municipal Solid Waste Management in India: A Sourcebook for Policy Makers and Practitioners, WBI Development Studies.

[6]. Fauth, D.J., Soong, Y., White, C.M., 2002, "Carbon Sequestration Utilizing Industrial Solid Residues", Symposium-American Chemical Society, Division Fuel Chemistry, 37-38. 
[7]. Gupta, A., Nema, A. K., 2011, "CO Sequestration Potential of Construction and Demolition Alkaline Waste Material in Indian Perspective", World Academy of Science, Engineering and Technology, 78.

[8]. Herzog, H., 2002, "Carbon sequestration via mineral sequestration: overview and assessment, MIT laboratory for energy and the environment.

[9]. Huijgen, W.J.J., Comans, R.N.J., 2003, "Carbon Dioxide Sequestration by Mineral Carbonation: Literature Review, Energy Resource Centre of the Netherlands, ECNC 03-016(February 2003). Available at www.ecn.nl (Accessed on $21^{\text {st }}$ August 2012).

[10]. Khandelwal, P. K., 2007, "Solid waste management in Delhi with experience on privatization of collection \& transportation of MSW, Municipal Corporation of Delhi, India", Available http://www.assocham.org (Accessed on $13^{\text {th }}$ August 2011).

[11]. Lackner, K.S., 2002, “Carbonate chemistry for sequestering fossil carbon", Annual Review of Energy and the Environment, 27, 193-232.

[12]. Lal, R., Follett, R.F. and Kimble, J.M., 2003, "Achieving soil carbon sequestration in the United States: a challenge to the policy makers", Soil Science, 168, 827-845.

[13]. Pappu, A., Saxena, M., Asolekar, S. R., 2007, "Solid wastes generation in India and their recycling potential in building materials", Building and Environment, 42(6), 2311-2320.

[14]. Reinhart, D. R., Townsend, T.G., 1998, "Landfill Bioreactor Design and Operation", Lewis Publishers, New York, 189.

[15]. Reinhart, D., Amini, H., 2008, "Landfill Gas to Energy Opportunities", Central District Power Generation Conference, University of Central Florida, Orlando, FL, USA. Available http://www.dep.state.fl.us/air/publication/po wergen/2008/landfillgas.pdf, (Accessed on $12^{\text {th }}$ July, 2012).

[16]. Sharholy, M., Ahmad, K., Vaishya, R.C., Gupta, R.D., (2006). Municipal solid waste characteristics and management in Allahabad, India. Journal ofWaste Management. 490-496.

[17]. Shekdar, A.V., Krshnawamy, K.N., Tikekar, V.G., Bhide, A.D., (1992). Indian urban solid waste management systems - jaded systems in need of resource augmentation. Journal of Waste Management. 379-387.
[18]. Singh, B.P., Kumar, A., Singh, Punia, M., Singh, D., Kumar, K., Jain, V. K., 2104. An assessment of ozone levels, UV radiation and their occupational health hazard estimation during photocopying operation. Journal of Hazardous Material, 275, 55-62.

[19]. Singhal S., Pandey,S., (2001). Solid waste management of India, status and future direction. TERI Information monitor on Environment Sciences. 6 (1), 1-4.

[20]. Tacoli, C., 2012, Urbanization, Gender and Urban Poverty: Paid Work and Unpaid Carework in the City, International Institute for Environment and Development: United Nations Population Fund, London, UK.

[21]. Thitame S. N., Pondhe G. M., Meshram D. C., (2010). Characterisation and composition of Municipal Solid Waste (MSW) generated in Sangamner City, District Ahmednagar, Maharashtra, India. Environ Monit Assess, 170:1-5

[22]. U.S. Environmental Protection Agency, 2005, "Inventory of U.S. Greenhouse Gas Emissions and Sinks", EPA 430-R-05-003.

[23]. UNPD, 2012a, World Urbanization Prospects, the 2011 Revision, Department of Economic and Social Affairs, Population Division, United Nations, New York. <http://esa.un.org/unup/pdf/WUP2011_High lights.pdf> (accessed 09.10.13). 